\title{
Eksperimen Sistem Sambungan Rotan Untuk Pengembangan Sarana Duduk Rotan
}

\author{
Ihsan Biantoro dan Ellya Zulaikha \\ Departemen Desain Produk Industri, Fakultas Teknik Sipil dan Perencanaan, \\ Institut Teknologi Sepuluh Nopember (ITS) \\ e-mail: ellya.zulaikha@gmail.com
}

\begin{abstract}
Abstrak. Industri mebel rotan terus meningkat dalam 3 tahun terakhir, terutama setelah Peraturan Menteri Perdagangan tentang pelarangan ekspor bahan baku mentah ini dikeluarkan. Sejak tahun 2012, nilai ekspor pada mebel rotan meningkat $57 \%$ dibandingkan tahun 2011 dan telah memberikan dampak positif bagi industri rotan di Indonesia. Kementerian Perdagangan merilis bahwa sebanyak $80 \%$ kebutuhan rotan dunia dipenuhi oleh Indonesia. Dengan perkembangan ini, diharapkan ada lebih banyak inovasi pada mebel rotan, baik dari segi desain maupun dari proses produksi.
\end{abstract}

Desain mebel rotan pada saat ini mengalami stagnansi pada inovasi. Berbeda dengan era 90 -an di mana era tersebut adalah era kejayaan mebel rotan di Indonesia. Dengan dasar tersebut, diperlukan langkah-langkah untuk menemukan inovasi baru penggunaan rotan pada mebel. Langkah atau metode yang digunakan adalah observasi, wawancara, dan eksperimen. Observasi yang pertama dilakukan untuk mengetahui desain yang sedang berkembang dan selera pasar pada saat ini melalui pengamatan pada beberapa pameran. Observasi yang kedua dilakukan untuk mengetahui proses produksi dan kemampuan produksi industri mebel rotan. Wawancara dilakukan pada ekspert yang bekerja dalam bidang mebel rotan dan sudah mendapatkan beberapa penghargaan tentang desain rotan yang membuktikan kompetensinya dalam bidang ini. Setelah itu dilakukan metode eksperimen. Eksperimen yang dilakukan berupa eksplorasi sistem joining dan struktur utama, untuk mencari kemungkinan kebaruan yang nantinya mampu menghasilkan kemungkinan desain yang baru.

Pada akhir penelitian ini, dihasilkan beberapa jenis join baru yang memberikan kesan dan desain baru pada mebel rotan. Join baru yang dihasilkan lebih bersih dari sisi desain dan memiliki komposisi bentuk baru yang tergolong menarik secara pasar.

Kata Kunci: Eksperimen, rotan, sistem sambungan.

Abstract. Rattan furniture industry was increasing in the last 3 years, especially after Minister of Trade's regulation issued about concerning the ban on export of raw materials. Since 2012, export value in rattan furniture was increasing $57 \%$ compared to 2011 and had a positive impact on the rattan industry in Indonesia. Ministry of Commerce released that as much as $80 \%$ of world rattan demand is fulfilled by Indonesia. With this development, it's expected that there will be more innovation in rattan furniture, both in design and production process.

The design of rattan furniture is currently stagnant in innovation. Unlike the $90 \mathrm{~s}$, when the glory age of rattan furniture in Indonesia. On this basis, steps are needed to find new innovations in the use of rattan on furniture. Methods used for this research are observation, interviews, and experiments. The first observations were made to find out the current developing design and market tastes through observations at several exhibitions. The second observation was conducted to find out the production process and production ability of rattan furniture industry. Interviews were conducted with rattan experts who working in rattan furniture and have earned several awards on rattan design so that can be proven their competence in this field. Experiments conducted in the form of exploration of the joining system and main structure, to find possibilities that will be able to produce in new design.

At the end of this study, several new types of joints were created that gave the impression and new designs on rattan furniture. The newly created joint is cleaner from the design side and has a new composition of shapes classified as attractive in the market.

Keyword: Experiment, rattan, joint system.

\section{PENDAHULUAN}

\section{A. LatarBelakang}

Rotan merupakan salah satu komoditi ekspor dari Indonesia yang menyuplai sekitar $85 \%$ kebutuhan rotan dunia [1]. Pada periode 1 Januari sampai dengan 30 September 2012, nilai produk ekspor mebel rotan di Indonesia telah mencapai USD 157 juta atau naik sekitar 57\% dibanding tahun 2011 sebesar USD 100 juta. Peningkatan ekspor produk jadi rotan pada tahun 2012 didorong oleh kebijakan pemerintah berupa peraturan menteri perdagangan nomor 35/M-DAG/PER/11/2011 tentang ketentuan ekspor rotan dan produk rotan yang melarang ekspor rotan mentah sehingga kebutuhan produk rotan dunia tergantung sepenuhnya pada produksi rotan di Indonesia [1], [2], [3] dan [4].

Pasar internasional memiliki minat yang sangat tinggi pada produk mebel berbahan baku rotan asal Indonesia. Namun, belum banyak peluang yang belum bisa dimanfaatkan lantaran produknya masih kalah bersaing atau belum memenuhi standar produk internasional. Untuk itu, perlu dilakukan pengembangan, khususnya pada desain produk rotan tersebut.

Sejauh ini belum banyak industri yang menggunakan rotan kecil sebagai struktur utama. Hal ini karena penggunaan rotan kecil tanpa bantuan support perekat oleh industri belum sampai pada tahap pengembangan dan struktur. Ada beberapa eksisisting dari sambungan yang selama ini digunakan dan sudah menjadi pengetahuan luas tentang struktur rotan. Sambungan rotan tersebut merupakan duplikasi dari sambungan-sambungan pada sambungan kayu sehingga kemampuan asli rotan yang merupakan material dengan elastisitas yang tinggi kurang bisa dioptimalkan [5], [6], [7] dan [8].

\section{B. Permasalahan}

1) Struktur rotan belum ada yang orisinil menggunakan sifat asli material rotan. 
2) Struktur yang digunakan selama ini menggunakan ikatan yang menambah lama pengerjaan.

3) Tidak ada kebaruan inovasi dalam bidang rotan khususnya pada struktur sambungan.

\section{BatasanMasalah}

1) Material utama menggunakan rotan dan material sekunder menggunakan kayu dan besi.

2) Desain mengacu pada mebel rotan yang sudah dan sedang diproduksi oleh industri terpilih.

3) Desain mebel yang dihasilkan berupa sarana duduk.

D. Tujuan

1) Mengoptimalkan penggunaan sifat asli rotan dengan sistem sambungan baru.

2) Mengefisiensikan waktu dan biaya produksi.

3) Menghasilkan desain dan inovasi baru mengacu pada penggunaan sambungan rotan dari eksperimen yang telah dilakukan.

\section{METODE PENELITIAN}

\section{A. Skema Riset}

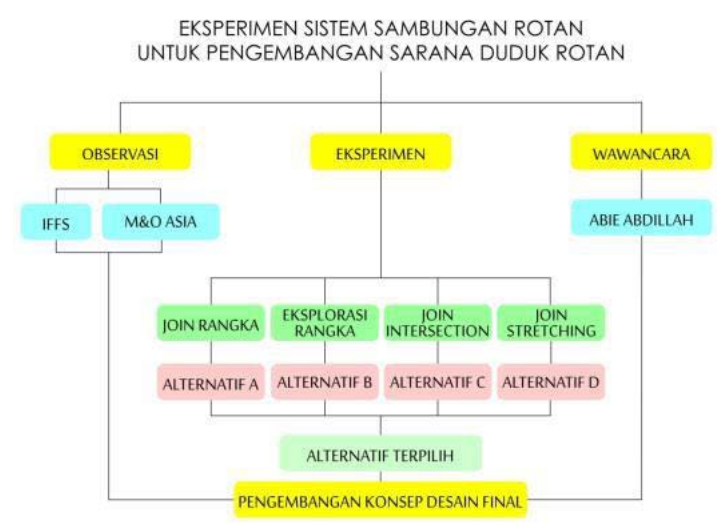

Gambar 1. Skema alur riset pada proses eksperimen sistem sambungan.

Setelah melakukan kajian berupa pengumpulan informasi literatur dasar tentang penelitian ini, maka diperlukan metode riset yang tepat untuk mencapai tujuan penelitian ini. Metode yang digunakan pada penelitian ini berupa observasi, wawancara dengan ahli/ekspert, dan eksperimen. Metode observasi digunakan sebagai acuan dari pengembangan desain terbaru dan selera pasar saat ini. Selanjutnya, data hasil observasi dikuatkan dengan wawancara pada para ahli dalam bidang rotan. Kemudian peneliti melakukan eksperimen pada rotan dilakukan dalam beberapa tahap dan mengacu pada penggunaan material non-rotan yang diterapkan pada rotan sehingga bisa menghasilkan pengembangan desain baru (Gambar-gambar 1 dan 2).

\section{B. Observasi}

Metode observasi ini dilakukan pada tanggal 12-15 Maret 2015 di Singapura dalam acara pameran desain yang digelar oleh Maison \& Objet Asia. Pameran ini termasuk dalam satu rangkaian acara Singapore Design Week 2015. Pameran Maison \& Objet Asia ini dihadiri lebih dari 200 perusahaan industri dan manufaktur dalam bidang produk home furnishing. Setelah pengamatan dasar dilakukan di pameran tersebut, akhirnya peneliti menjatuhkan pilihan kepada dua perusahaan asal Jepang yaitu Re-Mix Japan dan Karimoku untuk diobservasi lagi secara mendalam melalui pengamatan visual dan tanya jawab dengan desainernya.

\section{Wawancara dengan ahli}

Metode wawancara ini ditujukan kepada ahli di bidang rotan. Peneliti memilih Abie Abdillah sebagai narasumber karena selaku Wakil Ketua di Pusat Inovasi Rotan Nasional sejak tahun 2013. Penghargaan yang diperoleh Abie dalam bidang rotan antara lain: Honorable Mention of Singapore Mebel Design Awards (2011), Platinum Prize Winner di Indonesia Mebel Design Award (2011), Most Inspiring Mebel Design oleh Skala+ Magazine. Abie juga terpilih sebagai Asian Star Showcase di IFFS 2014, Rising Asia Talents di Maison \& Objet Asia 2015, dan Innovative Craft Awards 2015 di Thailand.

\section{Eksperimen}

Eksperimen ini dilakukan di 2 tempat sejak tanggal 26 Maret 2015. Tempat pertama adalah pabrik PT. Kalyana, Desa Mojosari, Mojokerto dan tempat kedua yaitu di bengkel Despro ITS Surabaya. Ada 4 konsep eksperimen yang dilakukan dalam penelitian ini, yaitu joint rangka, coiling, joint intersection dan joint stretching.
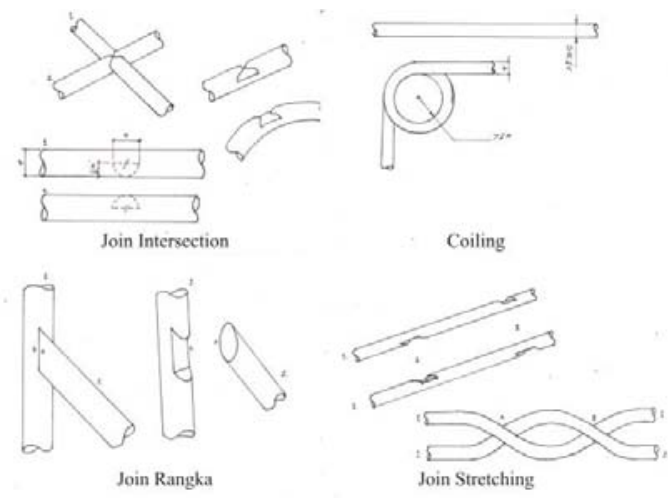

Gambar 2. Konsep eksperimen yang dilakukan dalam penelitian

\section{PEMBAHASAN}

\section{A. Studi Pasar}

Studi pasar dilakukan untuk membahas tentang pasar yang dituju, produk kompetitor dan range (kisaran) harga yang akan digunakan sebagai batasan dalam desain dan biaya produksi dalam penelitian ini (Gambar 3).

Mebel rotan yang kini sedang naik jumlah ekspornya dibandingkan penjualan retail domestik lainnya menghasilkan sebuah hipotesa adanya perbedaan selera dan gaya hidup pasar domestik dan pasar ekspor. Hal ini didapat melalui proses wawancara yang sebelumnya dilakukan pada tanggal 13 Maret 2015 di Marina Bay Sands, Singapura dalam acara Maison \& Objet Asia.

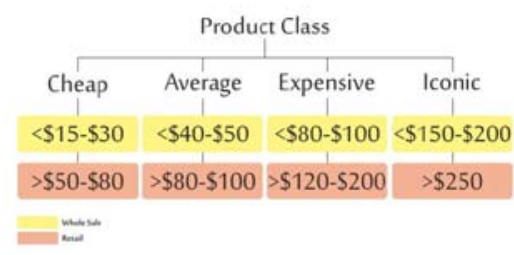

Gambar 3. Klasifikasi harga produk eksisting pasar.

Berdasarkan studi sebelumnya dapat ditarik beberapa kesimpulan untuk menentukan harga produk yang akan dibuat. Hal ini memberikan gambaran untuk produk yang akan dibuat dengan menggunakan range pada klasifikasi expensive dan iconic [9], [10], [11] dan [12]. 


\section{B. Studi Eksperimen}

Studi eksperimen yang dilakukan dalam penelitian ini adalah untuk menganalisa kelebihan dan kekurangan sebuah sistem join/sambungan, baik dari kekuatan, bentuk, lama pengerjaan dalam produksi, kebutuhan jenis dan jumlah rotan yang dipakai.

1. Konsep Joint Rangka.

Konsep joint rangka ini berangkat dari permasalahan join 45 derajat yang umum. Desain terbaru untuk joint 45 derajat sejauh ini menggunakan sambungan fish jaw dengan tambahan dowel kayu di dalamnya (Gambar 4).

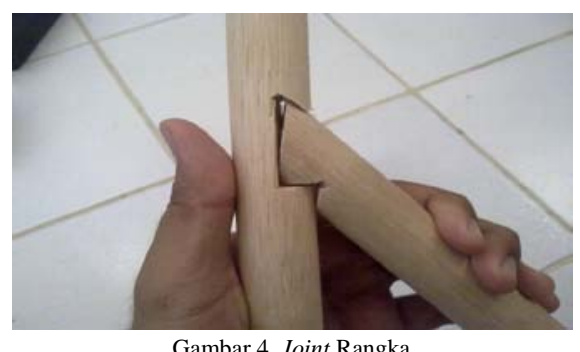

Gambar 4. Joint Rangka

\section{Konsep Coiling.}

Konsep coiling ini diterapkan dengan acuan coiling pada bambu. Pada dasarnya, penggunaan coiling ini dapat bervariasi secara ukuran (Gambar 5).

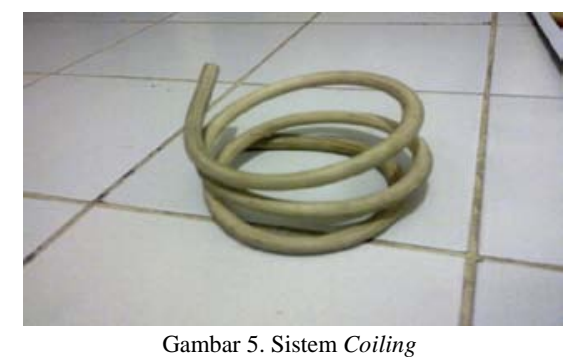

3. Konsep Joint Intersection.

Konsep joint intersection pada joint rotan 90 derajat tidak harus menggunakan bahan perekat seperti lem atau pengikat (Gambar 6). Bentuk ini didapatkan mengacu pada joint silang yang biasa ada pada kayu dan rotan.

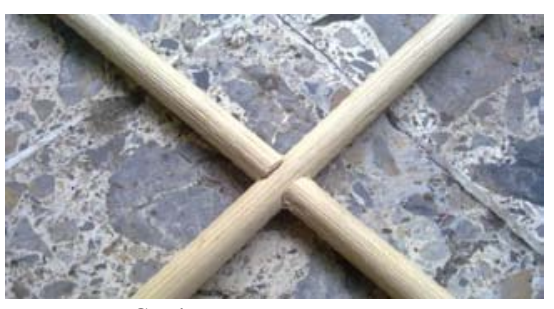

Gambar 6. Joint Intersection

4. Konsep Joint Stretching.

Konsep joint stretching merupakan pengembangan dari joint intersection. Konsep ini berawal dari sebuah hipotesa bagaimana anyaman kain dapat meregang dan dapat mempertahankan bentuknya (Gambar 7).

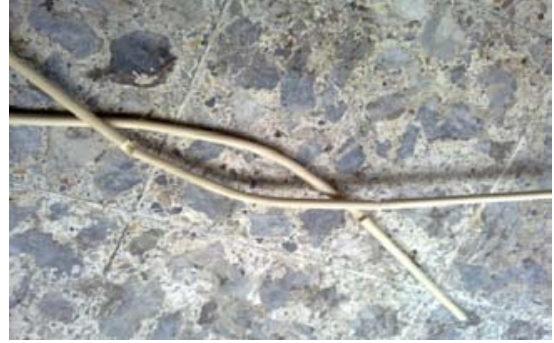

Gambar 7. Joint Stretching

Dari keempat eksplorasi yang telah dianalisa, muncul sebuah grafik tentang kemampuan rotan yang paling memungkinkan dengan kemampuan pabrik. Dari tiga poin pengembangan hanya dua poin yang digunakan, yaitu proses pengerjaan dan harga. Hal ini didasari oleh batas waktu penelitian yang sangat pendek, sehingga prioritas eksperimen yang dikembangkan tergantung dari 2 hal, pertama waktu yang tidak terlalu lama untuk pengerjaan pabrik dan tidak terlalu cepat untuk pengerjaan pengrajin, kedua adalah cost yang tidak terlalu mahal namun tidak terkesan murahan dari segi prosesnya.

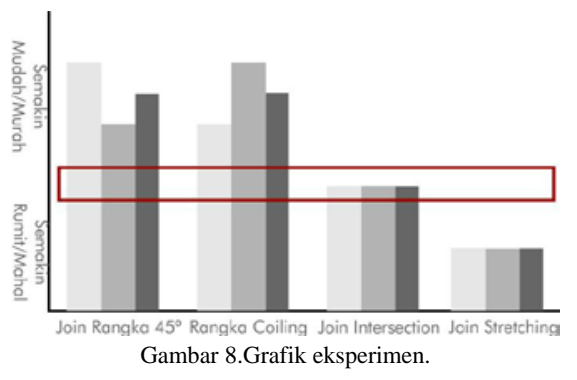

Dari Gambar 8 dapat diketahui bahwa fokus pengembangan eksperimen selanjutnya yang akan melalui proses prototiping adalah joint intersection.

\section{Implementasi Desain}

Implementasi desain pada penelitian ini berfokus pada sambungan intersection yang diwujudkan dalam bentuk produk sarana duduk. Melalui berbagai uji coba, muncul hipotesa terakhir pada prototipe ketiga. Hipotesis yang digunakan adalah "Penggunaan rotan ganda secara keseluruhan dan menghindari bentuk lengkungan pada struktur utama meningkatkan kekuatan struktur dan mempercepat proses produksi”. Konsep kursi dengan bentuk sederhana, mengutamakan kecepatan produksi, efisiensi bahan, serta support rangkap ada sandaran dan dudukan yang berbentuk datar.

Dari proses prototipe diperoleh beberapa analisa:

1) Rotan yang digunakan menggunakan rotan 15 sehingga lebih kuat.

2) Jarak antar sambungan pada sandaran dan dudukan terlalu besar sehingga masih menimbulkan gaya elastis yang cukup besar.

3) Lubang yang dibuat untuk memasukkan rotan core $15 \mathrm{~mm}$ tidak sesuai, lebih kecil $1 \mathrm{~mm}$.

4) Gaya elastis pada dudukan tidak merata sehingga cenderung lepas satu sama lain.

5) Penambahan jok membuat beban rata dan sambungan kuat menahan beban.

\section{KESIMPULAN}

Dari penelitian ini dapat disimpulkan beberapa poin penting tentang eksperimen yang telah dilakukan beserta pengembangan 
desainnya. Kesimpulan ini dapat diklasifikasikan menjadi bagian produksi dan desain.

Secara produksi, penelitian ini mampu mengoptimalkan karakter rotan yang lentur tapi kuat. Sejauh ini belum banyak industria yang menggunakan rotan kecil sebagai struktur utama.

Hal ini karena penggunaan rotan kecil tanpa bantuan perekat oleh industri belum sampai pada tahap pengembangan dan struktur. Di samping itu, dengan penggunaan sistem routering pada prosesnya, eksperimen ini memiliki keunggulan dengan penggunaan teknologi yang baru. Eksperimen semacam ini masih minim. Dengan demikian diperlukan edukasi terhadap pengrajin. Lama waktu yang dibutuhkan dalam pengerjaan ini pada dasarnya mengganti proses perekatan dengan rotan peel yang biasa digunakan untuk mengikat rotan. Namun, proses ini membutuhkan ketelitian yang cukup tinggi. Hal ini pulalah yang membuat kesulitan bagi pengerajin non industria yang terbiasa bekerja dengan tingkat presisi yang rendah.

Secara desain, penelitian ini mampu menumbuhkan sebuah desain yang tergolong modern. Didorong oleh struktur baru, desain yang mendukung struktur ini justru lebih modern dikarenakan tuntutan kesederhanaan bentuk namun kuat. Hal ini sangat berpotensi mengeluarkan desain-desain yang modern dan simple dengan biaya produksi lebih rendah dari estándar produksi desain rotan pada umumnya.

Dari penelitian ini memberikan beberapa alternatif pengembangan yang bisa dilakukan untuk penelitian selanjutnya. Pengembangan tersebut antara lain adalah inovasi pada pembuatan alat pendukung untuk produksi dan kombinasi sistem struktur. Ke depannya, penelitian ini masih bisa berkembang ke tahap yang lebih tinggi untuk penggunaannya dalam industri rotan, baik secara produksi maupun desain.

\section{DAFTARPUSTAKA}

[1] Hartono. 2013. Kemenperin Mendorong Pengembangan Industri Rotan Melalui Pendirian PIRNas. Kementerian Perindustrian Indonesia. Diakses 3 Maret 2015 dari situs http://www.kemenperin.go.id/artikel/5536/KemenperinMendorong-Pengembangan-Industri-Rotan-MelaluiPendirian-PIRNas

[2] Bagis, Husin. 2003. Mengenal Pasar Jepang. Diakses tanggal 21 Mei 2015, pukul 17:47 WIB dari http://www.kemendag.go.id/files/pdf/2012/12/08/peluangpasar-jepang-id0-1354945395.pdf

[3] Cookson, Andrew J., Shinnichi, Ishimura. 2009. The Early Development of English Rattan Seats. Kyuushu University: The 56th Annual Conference of JSSD.

[4] Darmawansyah, Rahmat. 2013. Hasil Hutan Non KayuRotan. Diakses tanggal 19 Maret 2015, pukul 02:57 WIB dari http://www.slideshare.net/jchikara/pengolahan-rotanrattan-processing

[5] Derringer, Jaime. 2011. STOOLS BY ABIE ABDILLAH. Diakses tanggal 23 Januari 2016, pukul 10:04 WIB http://design-milk.com/stools-by-abieabdillah/padatanggalPM

[6] Ekspor, Warta. 2013. Pengembangan Produk Mebel Rotan Indonesia. Jakarta: Kementrian Perdagangan RI. Ditjen PEN/MJL/35/VI/2013.

[7] Hartono. 2013. Kemenperin Mendorong Pengembangan Industri Rotan Melalui Pendirian PIRNas. Jakarta: Kementrian Perindustrian RI.

[8] Jasni. 1999. Sari Hasil Penelitian Rotan. Indonesia: Jurnal Departemen Kehutanan.

[9] Karmidi. 2009. Pengenalan Jenis Rotan. Diakses tanggal 9 Maret 2015, pukul 02:42 WIB dari situs: http://karmidi.blogspot.com/2009/08/pengenalan-jenisrotan.html
[10] Konsulat Jenderal Republik Indonesia. 2010. Kiat Memasuki Pasar Jepang. Osaka: Konsulat Jenderal Republik Indonesia. Diakses pada tanggal 21 Mei 2015 pukul 17:44 WIB dari situs: http://www.indonesiaosaka.org/informasi-umum/ekonomi/kiat-memasuki-pasarjepang/

[11] Maharani, Niken Yusnita. 2013. Eksplorasi Struktur dan Kombinasi Material Produk Mebel Rotan. Bandung: Laporan Tugas Akhir Program Studi Desain Produk FSRDITB.

[12] Ngakan, Putu Oka. 2006. Ketergantungan, Persepsi dan Partisipasi Masyarakat terhadap Sumber daya Hayati Hutan. Bogor: Center for International Forestry Research. 